\title{
Factors impacting social distancing measures for preventing coronavirus disease 2019 [COVID-19]: A systematic review
}

Krishna Regmi ( $\square$ Krishna.r.regmi@gmail.com )

University of Bedfordshire https://orcid.org/0000-0002-1408-1978

Cho Mar Lwin

University of Medicine Mandalay, Myanmar

\section{Systematic Review}

Keywords: Social distancing, COVID-19, COVID-19 pandemic, SARS-CoV-2, Prevention, Control, Systematic review

Posted Date: June 23rd, 2020

DOI: https://doi.org/10.21203/rs.3.rs-37498/v1

License: @ (i) This work is licensed under a Creative Commons Attribution 4.0 International License. Read Full License

Version of Record: A version of this preprint was published at International Journal of Environmental Research and Public Health on June 23rd, 2020. See the published version at https://doi.org/10.3390/ijerph18084274. 


\section{Abstract}

Background: Social distancing measures (SDMs) protect the health of the public from coronavirus 2019 (COVID-19) infection. However, the impact of SDMs has been inconsistent and unclear. This study aims to review the factors impacting SDMs (e.g. isolation, quarantine) for reducing the transmission of COVID19.

Methods: A systematic review was conducted. We searched MEDLINE, EMBASE, Allied \& Complementary Medicine, COVID-19 Research and WHO database on COVID-19 for primary studies assessing the enablers and barriers associated with SDMs, and reported in accordance with PRISMA statement. We used JBI Critical Appraisal Checklist for the cross-sectional survey and Qualitative Research to assess the methodological qualities and synthesised performing thematic analysis. Two reviewers independently screened the papers and extracted data.

Results: A total of 1235 citations were identified, of which 16 were found to be relevant. The studies reported in two broad categories, under seven separate themes: positive impact of SDMs, effective public health interventions, positive change in people's behaviour, worries and concerns about COVID-19, roles of mass media, physical and psychological impacts, and ethnicity/age associated with COVID-19.

Conclusion: The identified evidence signals that SDMs are generally effective for preventing or reducing transmission. There is a scope and need to find the best methods and approaches at the primary healthcare level in terms of developing objective measures and interventions to establish the link between different factors and SDMs and reducing transmission of COVID-19 trend effectively, efficiently and equitably.

\section{Background}

Coronavirus disease 2019 (COVID-19; caused by severe acute respiratory syndrome coronavirus 2 [SARS-CoV-2]), emerged in Wuhan, China in December 2019 , has been the biggest challenge for us in our lifetime posing a global public health threat. At the time of writing, WHO COVID-19 Situation Dashboard reported that this virus has already affected 216 countries with approximately 8,043,487 confirmed cases and 439,487 confirmed deaths; a fatality rate of $5.46 \%$, i.e. approximately 6 deaths in every 100 confirmed cases. The highest number of confirmed cases were reported in the Americas (3,899,859 [48.5\%]) followed by Europe (2,434,184 [30.2\%]), Eastern Mediterranean (817,458 [10.1\%]) and South-East Asia (503,034 [6.2\%]), whereas Western Pacific and Africa reported relatively low cases i.e. 200,586 [2.5\%] and 187,625 [2.3\%] respectively [1]. In Europe, the UK has become the 'epicentre' of the pandemic.

Based on reported cases and deaths, this disease is portrayed as a great equaliser, but 1:10 reported infections were among health professionals, e.g. medical doctors, nurses and other healthcare professionals. Evidence further indicates that in England, Black, Asian and Minority Ethnic (BAME) groups recorded higher mortality, ranging from 1.5 (in Asian) to 7.3 (in Black Caribbean population) times compared to white individuals [2]. Similarly, COVID-19 mortality rate in the US for African Americans was 2.4-2.7 times more than white individuals. However, deaths are not consistent across these groups. Several factors could be considered, e.g. ethnicity, age, sex, co-morbidities (diabetes, renal conditions), occupation, socioeconomic status, multifamily and multigenerational households [2-4].

Similarly, it is difficult to predict an exact future, but recent data from Johns Hopkins University reported that global COVID-19 deaths have surpass over 370,000 worldwide [5]. Imperial College London highlights that this outbreak could kill 40 million people this year without public health measures (e.g. case finding, contact tracing and testing, and strict quarantine) [6]. Evidence suggests that the number of cases reported would possibly "represent an underestimation of the true burden due to lack of surveillance and diagnostic capacity" [7] as well as pharmaceuticals to manage severe COVID-19 [8].

Several countries, including the UK, USA and other EU countries are adopting SDMs as a form of non-pharmaceutical or physical intervention. Social distancing is defined as a measure to ban large gatherings and advise individuals not to socialize outside their households by closing borders, some public places, schools and universities; isolation/quarantine, physical distancing and room separation to isolate symptomatic individuals and their contacts; and large-scale lockdowns of populations by staying at least $2 \mathrm{~m}$ apart [8] aiming to minimize mixing of infectious patients with susceptibles. WHO recommends case finding, testing, isolation, contact tracing and quarantine of close contacts [9].

A preliminary scan of the literature demonstrated some research on COVID-19 from China, South Korea, UK, USA and other countries, but these are very limited systemically reviewed or synthesised. Several rapid reviews and summaries have been covered on COVID-19 epidemiology [10,11], the effectiveness of real-time PCR for diagnosis [12], effects of school closure [13], quarantine [14,15], social distancing [16] (whose study was primarily based on two previous reviews [17,18] on influenza conducted in 2012 and 2018, respectively), and mathematical modelling studies incorporating the effect of social distancing [8,19-27]. These models would generally help to "predict epidemic curve representing the number of infections caused by the virus over time" [28].

Recently, few systematic review and meta-analysis conducted to investigate the optimum distance for avoiding transmissions [29] and ethnicity and clinical outcomes [4]. Cochrane further conducted three studies. First, a rapid review in 2020, involving 29 studies on COVID-19, SARS, MERS plus other viruses from China, UK, South Korea and Japan [30]. Second, a rapid qualitative evidence synthesis conduced in 2020 capturing 36 studies from Asia, Africa, Central and North America and Australia examined healthcare workers' adherence and enablers or challenges associated with infection control guidelines for respiratory infections. Another study examined 67 studies including RCTs and observational studies exploring the role of physical interventions for reducing the spread of respiratory viruses, and found no evidence regarding screening at entry ports and social distancing [31].

Lewnard and Lo [7] and Michigan Medicine Projections [32] reported that combined SDMs or interventions using social isolation, quarantine, school closure, and workplace distancing appeared effective in reducing COVID-19 compared to no interventions at all. This approach, however, reported considerable challenges, e.g. societal disruption, social isolation/rejection, mental stress and psychological trauma, lack of tests and testing facilities, poor contact tracing, lack of surveillance. None of these studies examined the SDMs factors in reducing the transmission of COVID-19 systematically. This systematic review aimed to examine the factors impacting SDMs for preventing COVID-19. 


\section{Review question}

What has been the impact of social distancing measures for preventing coronavirus disease 2019 [COVID-19]?

\section{Methods}

We conducted a systematic review (SR) to review relevant research literature, using systematic and explicit, accountable methods, to answer a specific research objective [33].

\section{Criteria for considering studies for review}

Inclusion criteria

1. Primary research describing SDMs, e.g. social distance, isolation and quarantine across all age-sex groups.

2. Research reporting enablers and barriers to implementing SDMs, e.g. social distance by avoiding crowds and restricting movement, isolating ill people and quarantine of exposed people for preventing transmission or controlling the spread of COVID-19 infections as outcome measures.

3. Published peer-reviewed article using quantitative (e.g. cross-sectional, randomised controlled trials, cohort, case-control) or qualitative (ethnography, grounded theory, phenomenological studies).

4. Articles published in English language regardless of the location (or settings) of the studies, up to June 2020.

Exclusion criteria

1. Articles published in narrative review, modelling studies, opinions, letters, news, editorials, perspectives, commentaries and any other publications lacking primary data, including grey literatures.

2. Studies deemed to have overall poor quality.

\section{Search strategy}

Five major databases were searched: MEDLINE, EMBASE, Allied \& Complementary Medicine, COVID-19 Research and WHO database on COVID-19. The literature search used the following terms: "social distancing measures", "social distancing", "quarantine", "patient isolation" combined with "CoVID-19". Five major databases were searched: MEDLINE, EMBASE, Allied \& Complementary Medicine, COVID-19 Research and WHO database on COVID-19. The literature search used the following terms: "social distancing measures", "social distancing", "quarantine", "patient isolation" combined with "COVID-19". Primary search terms were SDMs (all synonyms) and COVID-19 (all synonyms) using 'Textword searching'-searching for a word or phrase appearing anywhere in the document, where the document is the citation (article title, journal name, author), not the full text of an article, and 'Thesaurus (MeSH, EMTREE) searching', employing Boolean operators and truncations.

Authors developed a detailed study protocol with specific searching terms and strategies (Additional file 1). We utilised the 'Related Articles' including the best match and most recent features in PubMed. Searches were also supplemented by reviewing the reference lists ('references of references') of selected articles to find any other relevant papers. We contacted subject experts/information specialists from authors' Universities to verify the research strategy, ensuring its comprehensiveness. We also contacted some study authors to identify the additional studies. The literature search was conducted during May-June 2020 and the last search was conducted on 8 June 2020 in order to contemplate the recent pandemic crisis. The searchers were not limited by study design or study location.

\section{Selection of studies}

The citations identified through the searches were imported into Mendeley Reference Manager (https://www.mendeley.com/). All studies emerging from the databases have been screened twice: i) screening of abstracts and titles against minimum inclusion criteria, and ii) review of full text. We used the standard PRISMA flow diagram to provide the process of study selection [34] (Fig. 1). We also completed PRISMA checklist for this manuscript (Additional file 2).

\section{Quality appraisal of included studies}

We used JBI Critical Appraisal Checklist for the cross-sectional survey [35] and Qualitative Research [36] to assess the methodological qualities. All included studies were assessed by two reviewers (KR, CML) using the standardised eight and ten questions 4-item checklists i.e. Yes, No, Unclear and Not Applicable (Additional file 3 ) and the results have been used to inform synthesis and interpretation of the findings. To facilitate comparison of appraisal processes, all reviewers recorded the rationale for inclusion or exclusion, and discrepancies were discussed and resolved by consensus.

\section{Data extraction, analysis and synthesis}

Studies in this review were not sufficiently homogenous to analyse using meta-analysis [37]. Therefore, results are summarised using narrative synthesis and tabular form using thematic analysis (Table 2). Data extracted using the following summary data: sample characteristics i.e. study aim, study location, study

Page $3 / 19$ 
design, sample size, and appraisal checklist(s) and the overall reviewer comments. Thematic analysis/synthesis was used to identify the important or recurrent themes and the findings are summarised thematically [38]. Coding process and the development of themes were discussed among authors.

\section{Results}

The search results are summarised in Figure 1. In total, 1235 citations were identified, of which 16 were found to be relevant [39,40, 41-48, 49-54] excluded 68 studies.

\section{Quality of the studies}

We found 16 observational studies (with 71,465 participants). Of the 16,15 were quantitative cross-sectional surveys and one qualitative focus group study. All studies recruited participants online. Studies were conducted in 19 countries: three UK, three USA, three China, two Italy, and Canada, Hong Kong, Netherland, Germany, India, Paraguay, Saudi Arabia and Tanzania each with one study. Summary of the studies is in Table 1.

In general, these studies cover one or more of two areas: i) positive impacts (enablers) of SDMs for COVID-19, and ii) specific barriers to control or reduce transmission of COVID-19. Eight important themes under two broad descriptive themes emerged (Fig. 2). The relative contribution of each study to the synthesis is in Table 2 .

Table 1 Summary of reviewed studies 


\begin{tabular}{|c|c|c|c|c|c|c|}
\hline Study & Aims/study question & Country & Design/method(s) & $\begin{array}{l}\text { Number } \\
\text { of } \\
\text { subjects } \\
\text { (sample } \\
\text { size) }\end{array}$ & $\begin{array}{l}\text { Critical } \\
\text { appraisal } \\
\text { checklists* }\end{array}$ & $\begin{array}{l}\text { Reviewer } \\
\text { comments }\end{array}$ \\
\hline $\begin{array}{l}\text { Atchison et } \\
\text { al. [39] }\end{array}$ & $\begin{array}{l}\text { To examine risk perceptions and behavioural } \\
\text { responses of the UK adult population during the } \\
\text { early phase of the COVID-19 epidemic. }\end{array}$ & UK & $\begin{array}{l}\text { Cross-sectional } \\
\text { survey }\end{array}$ & 2108 & $\begin{array}{l}\text { Quantitative } \\
1,2,4,7,8\end{array}$ & $\begin{array}{l}\text { Lack of } \\
\text { methodological } \\
\text { details but } \\
\text { plausible } \\
\text { analysis. }\end{array}$ \\
\hline $\begin{array}{l}\text { Cowling et } \\
\text { al. [40] }\end{array}$ & $\begin{array}{l}\text { To examine the effect of these interventions and } \\
\text { behavioural changes of the public on the incidence } \\
\text { of COVID-19, as well as on influenza virus } \\
\text { infections, which might share some aspects of } \\
\text { transmission dynamics with COVID-19. }\end{array}$ & Hong Kong & $\begin{array}{l}\text { Cross-sectional } \\
\text { telephone survey }\end{array}$ & 3013 & $\begin{array}{l}\text { Quantitative } \\
1,2,4,7,8\end{array}$ & $\begin{array}{l}\text { Lack of } \\
\text { methodological } \\
\text { details but } \\
\text { plausible } \\
\text { analysis. }\end{array}$ \\
\hline $\begin{array}{l}\text { Gallè et al. } \\
{[45]}\end{array}$ & $\begin{array}{l}\text { To (i) evaluate the level of knowledge about the } \\
2019 \text {-nCoV, its spread and the control measures } \\
\text { adopted; (ii) analyze health-related behaviours } \\
\text { during lockdown, in order to estimate its possible } \\
\text { impact on personal habits; (iii) understand if the } \\
\text { study field may influence the level of knowledge } \\
\text { and lifestyle habits during the pandemic. }\end{array}$ & Italy & $\begin{array}{l}\text { Quantitative } \\
\text { survey }\end{array}$ & 2125 & $\begin{array}{l}\text { Quantitative } \\
1,3,7,8\end{array}$ & $\begin{array}{l}\text { Poor } \\
\text { methodological } \\
\text { details. }\end{array}$ \\
\hline $\begin{array}{l}\text { Hawryluck et } \\
\text { al. [47] }\end{array}$ & $\begin{array}{l}\text { To assess the level of knowledge about quarantine } \\
\text { and infection control measures of persons who } \\
\text { were placed in quarantine, to explore ways by } \\
\text { which these persons received information, to } \\
\text { evaluate the level of adherence to public health } \\
\text { recommendations, and to understand the } \\
\text { psychological effect on quarantine. }\end{array}$ & Canada & $\begin{array}{l}\text { Cross-sectional } \\
\text { survey }\end{array}$ & 129 & $\begin{array}{l}\text { Quantitative } \\
2,4,7,8\end{array}$ & $\begin{array}{l}\text { Some gaps in } \\
\text { methodology. }\end{array}$ \\
\hline $\begin{array}{l}\text { Katz et al. } \\
{[48]}\end{array}$ & $\begin{array}{l}\text { To identify key features of preparedness and the } \\
\text { primary concerns of local public health officials in } \\
\text { deciding to implement social distancing measures, } \\
\text { and determine whether any particular factor could } \\
\text { explain the widespread variation among health } \\
\text { departments in responses to past outbreaks. }\end{array}$ & USA & Online survey & 150 & $\begin{array}{l}\text { Quantitative } \\
1,2,4,7,8\end{array}$ & $\begin{array}{l}\text { Lack of } \\
\text { methodological } \\
\text { details but } \\
\text { plausible } \\
\text { analysis. }\end{array}$ \\
\hline $\begin{array}{l}\text { Pan et al. } \\
\text { [50] }\end{array}$ & $\begin{array}{l}\text { To evaluate the association of public health } \\
\text { interventions with the epidemiological features of } \\
\text { the COVID- } 19 \text { outbreak in Wuhan by } 5 \text { periods } \\
\text { according to key events and interventions. }\end{array}$ & China & $\begin{array}{l}\text { Quantitative } \\
\text { survey }\end{array}$ & 32,583 & $\begin{array}{l}\text { Quantitative } \\
2,4,7,8\end{array}$ & $\begin{array}{l}\text { Some gaps in } \\
\text { the } \\
\text { methodology. }\end{array}$ \\
\hline $\begin{array}{l}\text { Meier et al. } \\
{[49]}\end{array}$ & $\begin{array}{l}\text { To evaluate public belief in the effectiveness of } \\
\text { protective measures, to what extent individuals } \\
\text { have implemented these measures in their daily } \\
\text { lives, and to identify key communication channels } \\
\text { used to acquire information on COVID-19 in } \\
\text { European countries. }\end{array}$ & $\begin{array}{l}\text { Netherlands, } \\
\text { Germany } \\
\text { and Italy }\end{array}$ & $\begin{array}{l}\text { Cross-sectional } \\
\text { survey study }\end{array}$ & 9796 & $\begin{array}{l}\text { Quantitative } \\
1,2,3,4,7,8\end{array}$ & $\begin{array}{l}\text { Some gaps in } \\
\text { methodological } \\
\text { details but } \\
\text { plausible } \\
\text { analysis. }\end{array}$ \\
\hline $\begin{array}{l}\text { Wolf et al. } \\
\text { [43] }\end{array}$ & $\begin{array}{l}\text { To determine COVID-19 awareness, knowledge, } \\
\text { attitudes, and related behaviours among U.S. } \\
\text { adults who are more vulnerable to complications of } \\
\text { infection because of age and comorbid conditions. }\end{array}$ & USA & $\begin{array}{l}\text { Cross-sectional } \\
\text { survey }\end{array}$ & 630 & $\begin{array}{l}\text { Quantitative } \\
1,2,3,4,7,8\end{array}$ & $\begin{array}{l}\text { Few gaps in } \\
\text { methodological } \\
\text { details but } \\
\text { plausible } \\
\text { analysis. }\end{array}$ \\
\hline $\begin{array}{l}\text { Roy et al. } \\
\text { [52] }\end{array}$ & $\begin{array}{l}\text { To assess the knowledge, attitude, anxiety } \\
\text { experience, and perceived mental healthcare need } \\
\text { among adult Indian population during the COVID- } \\
19 \text { pandemic. }\end{array}$ & India & $\begin{array}{l}\text { Cross-sectional, } \\
\text { observational } \\
\text { study }\end{array}$ & 662 & $\begin{array}{l}\text { Quantitative } \\
1,2,7,8\end{array}$ & $\begin{array}{l}\text { Some gaps in } \\
\text { the } \\
\text { methodology. }\end{array}$ \\
\hline $\begin{array}{l}\text { Rios- } \\
\text { González } \\
{[51]}\end{array}$ & $\begin{array}{l}\text { To examine the knowledge, attitudes and practices } \\
\text { of the population about COVID- } 19 \text {. }\end{array}$ & Paraguay & $\begin{array}{l}\text { Cross-sectional } \\
\text { study }\end{array}$ & 3141 & $\begin{array}{l}\text { Quantitative } \\
2,3,7,8\end{array}$ & $\begin{array}{l}\text { Some gaps in } \\
\text { the } \\
\text { methodology. }\end{array}$ \\
\hline $\begin{array}{l}\text { Rugarabamu } \\
\text { et al. [41] }\end{array}$ & $\begin{array}{l}\text { To investigate KAP towards COVID-19 KAP among } \\
\text { residents in Tanzania during the April - May } 2020 \\
\text { period of the epidemic. }\end{array}$ & Tanzania & $\begin{array}{l}\text { Cross-sectional } \\
\text { study }\end{array}$ & 400 & $\begin{array}{l}\text { Quantitative } \\
2,4,7,8\end{array}$ & $\begin{array}{l}\text { Some gaps in } \\
\text { the } \\
\text { methodology. }\end{array}$ \\
\hline $\begin{array}{l}\text { Zhong et al. } \\
{[44]}\end{array}$ & $\begin{array}{l}\text { To investigate Chinese residents' KAP towards } \\
\text { COVID- } 19 \text { during the rapid rise period of the } \\
\text { outbreak. }\end{array}$ & China & $\begin{array}{l}\text { Cross-sectional } \\
\text { survey }\end{array}$ & 6919 & $\begin{array}{l}\text { Quantitative } \\
1,2,3,4,7,8\end{array}$ & $\begin{array}{l}\text { Some gaps in } \\
\text { methodology } \\
\text { but overall } \\
\text { convincing. }\end{array}$ \\
\hline Geldsetzer & To assess knowledge and perceptions about & $\begin{array}{l}\text { UK and USA } \\
\text { Page } 5 / 19\end{array}$ & Cross-sectional & 5974 & Quantitative & Some gaps in \\
\hline
\end{tabular}




\begin{tabular}{|c|c|c|c|c|c|c|}
\hline [46] & $\begin{array}{l}\text { COVID-19 among a convenience sample of the } \\
\text { general public in the United States and United } \\
\text { Kingdom. }\end{array}$ & & survey & & $2,3,4,7,8$ & $\begin{array}{l}\text { methodology } \\
\text { but overall } \\
\text { convincing. }\end{array}$ \\
\hline $\begin{array}{l}\text { Williams et } \\
\text { al. [42] }\end{array}$ & $\begin{array}{l}\text { To explore the perceptions and experiences of the } \\
\text { UK public of social distancing and social isolation } \\
\text { measures related to the COVID- } 19 \text { pandemic. }\end{array}$ & UK & $\begin{array}{l}\text { Qualitative - } \\
\text { focus group study }\end{array}$ & 27 & $\begin{array}{l}\text { Qualitative } \\
1,2,3,4,5,8,9,10\end{array}$ & $\begin{array}{l}\text { Some gaps in } \\
\text { methodology } \\
\text { but overall } \\
\text { convincing. }\end{array}$ \\
\hline $\begin{array}{l}\text { Al-Hanawi et } \\
\text { al. [53] }\end{array}$ & $\begin{array}{l}\text { To investigate COVID-19 knowledge, attitudes and } \\
\text { practices (KAP), and associated sociodemographic } \\
\text { characteristics among the general population. }\end{array}$ & $\begin{array}{l}\text { Saudi } \\
\text { Arabia }\end{array}$ & $\begin{array}{l}\text { Cross-sectional } \\
\text { study }\end{array}$ & 3388 & $\begin{array}{l}\text { Quantitative } \\
1,2,3,4,6,7,8\end{array}$ & $\begin{array}{l}\text { Few gaps in } \\
\text { methodological } \\
\text { details but } \\
\text { plausible } \\
\text { analysis. }\end{array}$ \\
\hline Liu et al. [54] & $\begin{array}{l}\text { To examine the protective effects of appropriate } \\
\text { personal protective equipment for frontline } \\
\text { healthcare professionals who provided care for } \\
\text { patients with coronavirus disease } 2019 \text { (covid-19). }\end{array}$ & China & $\begin{array}{l}\text { Cross-sectional } \\
\text { study }\end{array}$ & 420 & $\begin{array}{l}\text { Quantitative } \\
1,2,3,4,6,7,8\end{array}$ & $\begin{array}{l}\text { Few gaps in } \\
\text { methodological } \\
\text { details but } \\
\text { plausible } \\
\text { analysis. }\end{array}$ \\
\hline
\end{tabular}

*Numbers in this column signify the quality criteria from the critical appraisal checklist (Additional file 3) that studies were deemed to have met.

Table 2 The contribution of each study in a thematic synthesis 


\begin{tabular}{|c|c|c|c|c|c|c|c|c|c|c|c|c|c|}
\hline & $\begin{array}{l}\text { Atchison } \\
\text { et al. } \\
\text { [39] }\end{array}$ & $\begin{array}{l}\text { Cowling } \\
\text { et al. } \\
\text { [40] }\end{array}$ & $\begin{array}{l}\text { Gallè } \\
\text { et al. } \\
\text { [45] }\end{array}$ & $\begin{array}{l}\text { Hawryluck } \\
\text { et al. [47] }\end{array}$ & $\begin{array}{l}\text { Katz } \\
\text { et } \\
\text { al. } \\
{[48]}\end{array}$ & $\begin{array}{l}\text { Pan } \\
\text { et } \\
\text { al. } \\
\text { [50] }\end{array}$ & $\begin{array}{l}\text { Meier } \\
\text { et al. } \\
\text { [49] }\end{array}$ & $\begin{array}{l}\text { Wolf } \\
\text { et } \\
\text { al. } \\
{[43]}\end{array}$ & $\begin{array}{l}\text { Roy } \\
\text { et } \\
\text { al. } \\
\text { [52] }\end{array}$ & $\begin{array}{l}\text { Rios- } \\
\text { González } \\
\text { [51] }\end{array}$ & $\begin{array}{l}\text { Rugarabamu } \\
\text { et al. [41] }\end{array}$ & $\begin{array}{l}\text { Zhong } \\
\text { et al. } \\
\text { [44] }\end{array}$ & $\begin{array}{l}\text { Geldsetzer } \\
\text { [46] }\end{array}$ \\
\hline $\begin{array}{l}\text { Avoiding } \\
\text { crowds and } \\
\text { social events }\end{array}$ & & $\sqrt{ }$ & $\sqrt{ }$ & $\sqrt{ }$ & $\sqrt{ }$ & $\sqrt{ }$ & $\sqrt{ }$ & & $\sqrt{ }$ & & & $\sqrt{ }$ & \\
\hline $\begin{array}{l}\text { Reducing } \\
\text { reproduction } \\
\text { number to } \\
\text { avert a local } \\
\text { epidemic }\end{array}$ & $\sqrt{ }$ & $\sqrt{ }$ & & & & $\sqrt{ }$ & & & & & & & \\
\hline $\begin{array}{l}\text { Flatten the } \\
\text { peak of and } \\
\text { area under the } \\
\text { epidemic } \\
\text { curve }\end{array}$ & $\sqrt{ }$ & $\sqrt{ }$ & & & & & & & & & & & \\
\hline $\begin{array}{l}\text { Improve the } \\
\text { capacity and } \\
\text { capabilities of } \\
\text { the healthcare } \\
\text { system }\end{array}$ & $\sqrt{ }$ & $\sqrt{ }$ & & & $\sqrt{ }$ & & & $\sqrt{ }$ & & $\sqrt{ }$ & & & \\
\hline $\begin{array}{l}\text { Appropriate } \\
\text { use of } \\
\text { physical } \\
\text { measures, e.g. } \\
\text { hand } \\
\text { sanitizers, } \\
\text { handwash } \\
\text { and face } \\
\text { masks }\end{array}$ & & & & & & & $\sqrt{ }$ & & & & & & \\
\hline $\begin{array}{l}\text { Border } \\
\text { restrictions, } \\
\text { school and } \\
\text { border } \\
\text { closures to } \\
\text { suppress } \\
\text { transmission }\end{array}$ & & $\sqrt{ }$ & & $\sqrt{ }$ & & & & & & & & & \\
\hline $\begin{array}{l}\text { Using } \\
\text { multifaceted } \\
\text { public health } \\
\text { interventions } \\
\text { (including } \\
\text { border entry } \\
\text { restrictions, } \\
\text { quarantine } \\
\text { and isolation } \\
\text { of cases and } \\
\text { contacts) }\end{array}$ & $\sqrt{ }$ & $\sqrt{ }$ & & & & $\sqrt{ }$ & $\sqrt{ }$ & $\sqrt{ }$ & $\sqrt{ }$ & $\sqrt{ }$ & & & $\sqrt{ }$ \\
\hline $\begin{array}{l}\text { Changing } \\
\text { population } \\
\text { behaviour, } \\
\text { such as social } \\
\text { distancing } \\
\text { and personal } \\
\text { protective } \\
\text { measures }\end{array}$ & & $\sqrt{ }$ & & & & & & & & & & & \\
\hline $\begin{array}{l}\text { Maintain } \\
\text { personal } \\
\text { hygienic } \\
\text { measures }\end{array}$ & & & & & & & $\sqrt{ }$ & & $\sqrt{ }$ & & & & \\
\hline $\begin{array}{l}\text { Compliance } \\
\text { with the } \\
\text { government } \\
\text { actions }\end{array}$ & $\sqrt{ }$ & $\sqrt{ }$ & $\sqrt{ }$ & & & & & & & & & & \\
\hline $\begin{array}{l}\text { Behavioural } \\
\text { changes or } \\
\text { interventions } \\
\text { which are less } \\
\text { disruptive } \\
\text { than total } \\
\text { lockdown }\end{array}$ & & & $\sqrt{ }$ & & & & & & & & & $\sqrt{ }$ & \\
\hline About the & & $\sqrt{ }$ & & $\sqrt{ }$ & & $\begin{array}{c}\sqrt{ } \\
\text { Page }\end{array}$ & $\begin{array}{l}\sqrt{ } \\
/ 19\end{array}$ & & & $\sqrt{ }$ & & & \\
\hline
\end{tabular}


current and

second waves

or outbreaks

Uncertainty

about the

duration of

the measures

Lack of trust

in

governments

Lack of clarity

and

$\sqrt{ } \sqrt{ } \quad \sqrt{ }$

understanding

Not receiving

the support

expected

Guidance on

social

distancing

and isolation

are vague

Media

constantly

giving or

reporting

wrong

information

about the

pandemic

status -

resulting in

emotional

exhaustion

Worried after

seeing posts

about COVID-

19 pandemic

on various

social media

platforms

Media

affecting

mental

wellbeing and

adding to the

level of

anxiety

Fear and

anxiety

Increased

quarantine

associated

with post-

traumatic

stress

disorder and

depression;

decrease of

physical

activity

Loss of social

interaction

and loss of

self-worth

Lack of social

and physical

contact.

Lost job or

income and

relying on

parental,

familial or

state financial

support

COVID-19

associated

$\sqrt{ }$

$\sqrt{ } \sqrt{ }$


Note: Shading indicates a study was rated as having low quality in terms of the methodological details

Enablers

Theme 1. Positive impact of social distancing measures

Theme 2. Effective public health interventions

Theme 3. Positive changes in people's behaviour

Barriers

Theme 4. Worries and concerns about COVID-19

Theme 5. Debatable role of mass media

Theme 6. Physical and psychological impacts

Theme 7. Ethnicity, age and COVID-19 pandemic

\section{Theme 1. Positive impact of social distancing measures}

Eleven out of 16 studies identified some positive impacts of different SDMs used to reduce transmission of COVID-19 [39-41,43-46,48,50,51,54]. The commonest SDMs were: avoiding crowds, border restrictions, isolating in the hospital, appropriate use of PPEs, working from home primarily to reduce the effective reproduction number of SARS-CoV-2 ( $R_{0}$, secondary transmission) $[39,40,46,54]$.

One study has highlighted that:

Without strengthening SDMs, local infections are likely to continue occurring, given that the effective reproduction number $\left(R_{o}\right.$ ) is approximately 1 or slightly higher. Travel measures and testing, tracing, and treating efforts are particularly important in maintaining suppression, although these measures will be increasingly difficult to implement as case numbers increase [40].

Similarly, other studies further added that if the basic reproduction number of COVID-19 in Hong Kong, UK and US exceeds 2, (it was 2.2 in Wuhan), we would need $>44 \%$ reduction in COVID-19 transmission to completely avert a local epidemic. A reduction of this magnitude could, however, substantially flatten the peak of and area under the epidemic curve, thus reducing the risk of exceeding the healthcare system capacity, potentially saving many lives, especially older adults $[39,40,42,44,51]$.

Studies reported that quarantine, and school and border closure have been the most effective means of suppressing transmission [40,43]. The commonest factors associated with SDM success are support on governmental measures for social distancing and isolation by avoiding crowds, closure of public places, hand hygiene, and individuals' adherence to country-specific mitigation measures $[45,48]$.

\section{Theme 2. Effective public health interventions}

Ten out of 16 studies reported the importance of public health interventions for COVID-19 [39,40,42,45-49,51,52]. Several studies perceived washing hands with soap, and avoiding crowds and social events as the most effective measures $[39,42,45,47,54]$. Several studies from different parts of the world reported that multifaceted public health interventions including personal protective equipments (PPEs), e.g. facemasks, eye protection, have been successful as the virus spreads through multiple channels, e.g. touching, sneezing.

The extracts below illustrate this:

The package of public health interventions (including border entry restrictions, quarantine and isolation of cases and contacts, and population behaviour changes, such as social distancing and personal protective measures) that Hong Kong has implemented since late January, 2020, is associated with reduced spread of COVID-19 [40, p. p. e284]. 
The study participants reported frequent use of sanitizers, hand wash, and masks during the past week. This indicates participants' increasing concern towards personal hygienic measures. Awareness about COVID-19 is reflected in behaviour and attitude as most participants agreed with social distancing, avoiding travel, self-quarantine and adequate hygiene $[48, \mathrm{p} .4]$.

\section{Theme 3: Positive changes in people's behaviour}

We found four studies (of 16) reported SDMs influenced people's behaviour [39-41, 53]. Atchison et al. [39] reported that part of the success in early February 2020 was changing people's behaviour to comply with government actions.

The extracts below illustrate this:

Social distancing and population behavioural changes with social and economic impacts less disruptive than total lockdown can meaningfully control COVID-19. Control measures and changes in population behaviour coincided with a substantial reduction in influenza transmission in early February, 2020. This observation suggests the same measures would also have affected COVID-19 transmission in the community, because of some similarities, as well as differences, in the modes of transmission of influenza and COVID-19 [40, p.e285].

Avoiding close contact, washing hands and wearing facial masks were considered the most protective measures [41, p.5].

\section{Barriers}

\section{Theme 4: Worries and concerns about COVID-19}

Eight out of 16 studies reported some concerns about the current pandemic and a possible second wave of COVID-19 [39,40,42,43,47,49-51]. The commonest associated factors were: (i) uncertainty about the duration of measures, and their ability to cope longer-term [42, p.1], and (ii) lack of trust in public health officials and governments due to lack of clarity about information on infection and what SDMs are effective against COVID-19 [49,51].

The extracts below illustrate this:

Overall, $77.4 \%$ (1640/2108) of respondents reported being worried about COVID-19 in the UK. For those not previously testing positive for COVID-19, 47.5\% $(979 / 2108)$ believed it was likely they would be infected at some point in the future under the UK Government's preventive measures. If infected, just over half (56.9\%) would expect to be moderately severely affected (e.g. may need self-care and rest in bed) [39, p.7].

Most participants felt that guidance on social distancing and isolation had been generally unclear, although some described how it had "become clearer". Many participants exhibited lack of trust in government or in the media [42, p.12].

\section{Theme 5. Debatable role of mass media}

Two of 16 studies identified this as a barrier [45,52]. These studies found that rumours in social media, and electronic and print media during SDMs (isolation, self-quarantine), and total restriction of travel (curfew) were associated with negative impact on mental health as they constantly depict the pandemic and deaths related to it. Therefore, people become angry, restless, worried, have difficulty coping, and feel emotionally exhausted [52].

One study observed that:

Approximately $28 \%$ of people report sleep difficulties. More than two-thirds of participants reported themselves worried after seeing posts about COVID-19 on social media [52, p.2].

Approximately $46 \%$ of participants reported worry regarding discussion of COVID-19 in news channels and print media. This indicates a significant proportion of survey participants, despite having adequate awareness about coronavirus infection, are largely influenced by media information. Media influences mental wellbeing and adds to anxiety levels [52, p.6].

\section{Theme 6: Physical and psychological impacts}

Four of the 16 studies identified these barriers [42,45,47,52]. The commonest associated factors were: anxiety [47], increased time in quarantine associated with post-traumatic stress disorder, depression [47], decrease in physical activity [45], loss of social interaction, and emotional and psychological distress [42].

The extracts below illustrate this:

The mandated lack of social and, especially, physical contact with family members were identified as particularly difficult. Confinement at home and work, being unable to see friends, being unable to shop for basic necessities of everyday life, and being unable to purchase thermometers and prescribed medications enhanced their feeling of distance from the outside world [47, p.10]. 
All participants felt that the social distancing and isolation polices had had significant social and psychological impacts on their lives and the central theme was loss [...]. These emotional and psychological losses were particularly acute for those living in more urban, densely populated cities like London or Birmingham. They were also especially evident amongst those in low-paid or precarious occupations, who had either lost their job or income or were now relying on parental, familial or state financial support as a result of the pandemic [42, p.10].

\section{Theme 7: Ethnicity, age and COVID-19 pandemic}

We found eight studies that evaluated differences across demographic and socio-economic strata, age and COVID-19 pandemic [39,41-43,46,47,50,53]. These studies found that COVID-19 was often associated with people from Black, Asian and minority ethnic (BAME) populations in lower socio-economic groups, employment in lower band/category, other comorbidities, exposure risks and older age.

The extracts below illustrate this:

More disadvantaged backgrounds were less likely to be able to work from home or self-isolate if needed, suggesting structural barriers to adopting preventive behaviours in these groups. The most economically disadvantaged in society are less able to comply with certain NPIs, likely partly due to their financial situation [39,p.17].

Adoption of SDMs was almost twice as likely in people over 70 compared to adults aged 18 to 34 . Notably, those that were single were less likely to practise social distancing. There was a strong association between socio-economic deprivation and ability to adopt NPIs [39,p.15; 43,p.6].

Fig. 3 is a conceptual framework (CF) that emerged from this study, which shows the interconnection of SDMs, factors and reducing COVID-19. To make the effective link between them, all these components are essential; putting people at the centre of the framework, ensuring their needs are appropriately met by providing best-quality care. As the first point of contact for patients or users, primary healthcare would play a key role. The approach would also help to reduce the basic reproduction number $\left(R_{o}\right)$ to avert a local epidemic and flatten the peak of and area under the epidemic curve. $R_{o}$ is considered a key indicator to assess "whether a pathogen introduced into a community will spread and, significantly gives guidance as to its rate of spread" [53,p.2]. Generally, it is expected to be below 1.0. This CF also acknowledges the capacities and capabilities of primary healthcare systems, health inequalities, social determinants of health, including the capacity of the national laboratory system that appropriately followed the WHO's mantra of "trace, test, and treat" to suppress and control the coronavirus epidemic [8,11]. Similarly, CF recognises societal norms, culture and values, as each country has its own specific geo-socio-economic, political, legal and cultural contexts.

\section{Discussion}

This study was undertaken to synthesise the evidence concerning SDMs to reduce transmission of COVID-19. The main finding of this research is that there is very limited evidence available in the peer-reviewed literature of well evaluated examples of the impact of SDMs in reducing transmission of COVID-19.

In this study, we found major factors, enablers or barriers, impacting SDMs emphasising the positive roles of SDMs, public health interventions, behaviour changes, people's worries and concerns, myths and stigma and physical and psychological impact including the debatable role of media. Similar issues have been documented in different literatures $[54,55]$. The purpose of social distancing is to inhibit the intensity of transmission $\left(R_{o}\right)$ to reduce $R_{o}$ to $<1$ or "contain the outbreak within a manageable duration" [56, p.2]. The ultimate strategy is to slow down or curb the spread of the overall disease burden-morbidity, severity, fatality, health complications and socio-economic consequences-and reduce the impact on health services. Anxiety or worries about the duration of quarantine have been highlighted in this study. A similar issue has also been reported in previous studies. Sjödin et al. [56], for example, based on the experience of the COVID-19 outbreak in Italy, discussed that for an average household of three persons, approximately $30-54$ days will be enough quarantine with near-complete and medium adherence community quarantine adherence respectively, assuming $10 \%$ asymptomatic infections. In this case, seven secondary cases would be expected in a population of 5000 , or 70 secondary infections in a population of 50,000 , assuming $10 \%$ asymptomatic infections.

This study found that social distancing has been effective only if integrated with enhanced personal hygiene, environmental sanitation and adequate and appropriate use of PPE (use of masks, handwashing, coughing etiquette). Early diagnosis and prompt management of confirmed cases by isolating (physical distance), timely follow-up and quarantine recommendations (14 days) for close contacts of a case constitute the CORE of COVID-19 control. This finding is consistent with conclusions of a study conducted by Chu et al. [29] i.e. "The risk for infection is highly dependent on distance to the individual infected and the type of face mask and eye protection worn. From a policy and public health perspective, current policies of at least $1 \mathrm{~m}$ physical distancing seem to be strongly associated with a large protective effect, and distances of $2 \mathrm{~m}$ could be more effective". ECDC report [57,p.3] highlighted that: "The success of social distancing measures that are implemented over an extended period may depend upon ensuring that people maintain social contact-from a distance-with friends, family and colleagues" as well as the strictness of quarantine adherence, household size, and highest rates of compliance [53,56]. Similar issues have also been reported by the findings of our study.

However, very little was known on our specific research question on the extent and the factors impacting SDMs in reducing transmission of COVID-19 nationally and globally, as there were no previous systematic reviews on this subject, or commentaries examining the factors associating SDMs and COVID19. There are, however, some rapid reviews, summaries and mathematical modelling studies covering COVID-19, in China, South Korea, UK, USA, and other countries, but the literature has not been systemically reviewed or synthesised. Similarly, the implementation of social distance differs by country due to the wide range of predictors associated with this measure, some far more strict than the UK, with Sweden at the opposite end of the spectrum. Therefore, it is difficult to assess which specific SDMs or measures would have a higher impact on the effects of social distancing to reduce transmission.

Page $11 / 19$ 
Lack of awareness and misconceptions about COVID-19 and the physical and psychological impacts due to lockdowns have been reported in the included studies, and similar findings were reported from previous studies [58]. Therefore there is a need to intensify awareness, education and campaigns, targeting general and specific spheres of populations, utilising internet-based information, use of social influencers, education and counselling (IEC) strategies to correct these misconceptions and provide support by different stakeholders (governments, NGOs, charities, national volunteers, community support groups). Increased media coverage would be one key strategy to make SDMs successful $[46,52,57]$.

In this study, we also found compliance has been one important factor, but it was not easy for securing public compliance in liberal democratic societies. Similarly, the approach in authoritarian regimes, e.g. China, would likely be unacceptable in other parts of the world. Related to this is how long restrictive measures can be tolerated, which lacks solid evidence [56,59]. Moreover, social distancing becomes a highly charged topic creating a lieu of debate among the politicians, economists, medical and public health professions. The likelihood is that COVID-19 will become endemic, which suggests long-term behavioural adjustments as reported in our study [45]. Similarly, we argued that social distancing is not part of the culture in either developed or developing countries, for different reasons [60]. In developing countries, it is more related to population density, crowding, workplace conditions etc., such as overcrowding in public transport. In developed countries such as Switzerland, people were still following Swiss kiss as late as 20 March, when COVID-19 was already peaking. Similarly, our study found a relationship between social distancing and economic aspects: poverty, living in slums etc. in developing countries; marginalized populations in developed countries. A similar issue has also been reported in the previous studies [61-63]. Therefore, there is a need to completely change the way the economy, businesses, and life are organised to protect the vulnerable groups such as homeless, disabled, undocumented migrant workers and inmates. Similarly, home life should be looked at, as evidence suggests we need to change the way we interact at home, for example, with vulnerable family members-elderly, pregnant, immunocompromised due to chronic disease or protracted illnesses, at least until the pandemic is over, e.g. curbing the possibility of transferring the disease to the elderly.

Moreover, we found that due to lockdown, people lost their jobs affecting their income and suffered job insecurity in general, but it disproportionately affects the most disadvantaged populations. These findings are consistent with the previous studies [2-4]. A recent descriptive review of data on disparities in the risk and outcomes from COVID19 in the UK has reported that:

"The largest disparity found was by age. Among people already diagnosed with COVID19, people who were 80 or older were seventy times more likely to die than those under 40. Risk of dying among those diagnosed with COVID-19 was also higher in males than females; higher in those living in the more deprived areas than those living in the least deprived; and higher in those in Black, Asian and Minority Ethnic (BAME) groups than in White ethnic groups" [3,p.4].

Marmot et al. [64] also argued that: "There are clear socioeconomic gradients in preventable mortality. The poorest areas have the highest preventable mortality rates and the richest areas have the lowest" (p.13). Finally, this study along with other evidence suggests that our health systems have not been proactive enough to cope with the current pandemic [54]. We argue that public health has failed to convince politicians to take rapid action on prevention of spread or prepare for necessary treatment arrangements. These findings are consistent with those of Pollock et al. [65] and Regmi et al. [66] and they found that the "structure and capacity of our depleted healthcare system are now largely driving the response to this epidemic" and most likely "it will continue to do so until services that support local communicable disease control are rebuilt and reintegrated".

This study adds to the literature on highlighting the major enablers and barriers of SDM in controlling COVID-19 in public health policy and interventions: i) given the fact that there is no vaccine or treatment available at the time of writing, and ii) there have been limited robust published studies of SDM success factors, with most studies exploring the process rather than hard or tangible outcomes. This scarcity of empirical studies demonstrates the practical realities, e.g. factors or outcomes of SDM would be appropriate for policy-planners, researchers and decision-makers to make it effective.

\section{Strengths and limitations of the review}

To our knowledge, this study might be the first systematic review to examine the enablers and barriers impacting SDMs to reduce transmission of COVID-19. It used a systematic and rigorous search strategy developing a systematic review protocol. This study has proposed a conceptual framework (CF) embedding an enablers, barriers and possible outcomes (EBO) configuration, putting people at the centre of the process, making sure that primary healthcare services are accessible to all (Fig. 3). This study also highlighted the themes from the interpretative synthesis and relative contribution of each study (Table 2). This CF has also recognised that the effectiveness of SDMs will depend on the credibility of public health authorities, and on strong leadership and commitment from political leaders and institutions.

This review has, however, several limitations. First, as it was not externally funded, and therefore time and resource were constrained and unable to include and review grey literature. Second, studies are variable in sample size, quality and population, which are open to bias, and the heterogeneity of data precludes a meaningful meta-analysis to measure the impact of specific enablers or barriers, therefore the findings warrant generalisation.

Third, despite the overall satisfactory methodological quality of the included papers, methodologies were poorly reported (mostly those preprints - postings in MedRxiv), lacking comprehensive strategies for sampling and procedures, and lacking detail in data gathering and analysis, including identifying and dealing with possible confounding factors (Table 1).

Wolkewitz and Puljak [67] further warned that: "there are many methodological challenges related to producing, gathering, analysing, reporting and publishing data in condensed timelines required during a pandemic." Finally, searching "social distancing" in different databases produced no results. We noticed that the problem of searching for SDMs and COVID-19 studies was mainly due to rapidly-growing COVID-19 studies in PubMed and other search interfaces, which are not visible in the major search databases (PubMed, EMBASE) due to i) indexing, and ii) often bibliographic databases failed to capture preprint and unpublished studies including registered clinical trials [68,69], and the majority are commentaries, news, perspectives or opinions [67]. Though Shokraneh [68]

Page $12 / 19$ 
provided some useful links specific to COVID-19 resources, still we found this difficult and time-consuming and the systematic search strategies noted lack of specificity.

\section{Directions for Future Research}

It is important to determine whether we should look to determine to develop herd immunity. If that is the case then "how can one determine how much herd immunity is sufficient to mitigate subsequent substantial outbreaks of COVID-19?"[70]. In addition, many frontline healthcare professionals are dying from COVID-19 and so research needs to find out why and how ethnicity, migrant status, health inequalities and social determinants of health (SDH) have links with COVID-19 [2,50,71]. It would also be beneficial to see the reasons why children and young people are least affected [72], why some patients develop more serious complications than others [57,(73)73], why do some COVID-19 patients infect many others, whereas most don't spread the virus et all? [74], and what has been the impact of different public health policies and efforts for COVID-19 by gender and age [75]. Similarly, we also need to determine whether the mass testing of antibody status would guide how extensively and how long social distancing should be implemented in a specific area [28, 70], and whether the term 'spatial distancing' would be more appropriate than 'social distancing measures' while addressing the issue of distance between individuals or objects [76]. Finally, we need to know what appropriate quarantine measures would be appropriate in the long run to curb importation of transmission, and whether "flattened epidemic curve [will] rise again once we come out of the quarantine adopted worldwide" [28].

\section{Conclusion}

The current systematic review highlights the importance of SDMs in the context of global uncertainty. This study provides useful factors-enablers and barriers-to implement and deliver SDMs policy in reducing transmission of COVID-19 and improving health and wellbeing. From this study, the identified evidence signals that SDMs are generally effective for preventing or reducing transmission. Based on the results of this study, we consider that targeted approaches alongside social distancing might be the way forward and more acceptable: reduce infection rate to make large-scale testing logistically viable, contact tracing, compliance rate, duration of measures, isolation for positive cases and teams to carry this out. Globally, health systems now, more than ever, face major challenges as they not only need to deal with unwell people but also continue to deliver public health - preventive measures. The best solution for a health system under pressure is to strengthen primary health care by assessing these factors in future monitoring/evaluation. Further research may be warranted to find the best methods and approaches in terms of developing objective measures and interventions to establish the link between different factors and SDMs (as a secondary outcome) and reducing transmission of COVID-19 trend (as a primary outcome) effectively, efficiently and equitably.

\section{Abbreviations}

\section{Ethics approval and consent to participate}

Not ethics approval or consent to participate was required.

\section{Consent for publication}

The authors give consent for publication of this manuscript

\section{Availability of data and materials}

Not applicable

\section{Competing interests}

The authors declare that they have no competing interests

\section{Funding}

The authors received no financial support for this research study.

\section{Authors' contributions}

KR conceived and designed the research with the advice from CML; KR and CML reviewed, analysed and interpreted the data and contributed to drafting, revising and finalising the manuscript. The authors read and approved the final manuscript.

\section{Acknowledgments}

Not applicable

\section{References}

1. World Heath Organisation (2020). Coronavirus disease (COVID-19). Pandemic. Retrieved from https://www.who.int/emergencies/diseases/novelcoronavirus-2019.

2. Razaq A, Harrison D, Karunanithi S, Barr B, Asaria M, Khunti K (2020). BAME COVID-19 deaths-what do we know? Rapid data \& evidence review: "hidden in plain sight". Retrived from https://www.cebm.net/wp-content/uploads/2020/05/BAME-COVID-Rapid-Data-Evidence-Review-Final-Hidden-in-Plain-Sight- 
compressed.pdf

3. Public Health England. Disparities in the risk and outcomes from COVID-19. London: PHE publications; 2020.

4. Pan D, Sze S, Minhas JS, Bangash MN, Pareek N, Divall P, et al. The impact of ethnicity on clinical outcomes in COVID-19: A systematic review. EClinicalMedicine. 2020;100404.

5. Feuer W (2020). Worldwide coronavirus cases top 200,000, doubling in two weeks. Retrived from https://www.cnbc.com/2020/03/18/worldwidecoronavirus-cases-top-200000-for-the-first-time.html

6. van Elsland SL, O'Hare R (2020). Coronavirus pandemic could have caused 40 million deaths if left unchecked. Retrived from https://www.imperial.ac.uk/news/196496/coronavirus-pandemic-could-have-caused-40/

7. Lewnard JA, Lo NC. Scientific and ethical basis for social-distancing interventions against COVID-19. Lancet Infect Dis. 2020;20(6):631-633.

8. Flaxman S, Mishra S, Gandy A, et al. Estimating the effects of non-pharmaceutical interventions on COVID-19 in Europe. Nature. 2020;10.1038/s41586020-2405-7. doi:10.1038/s41586-020-2405-7

9. World Health Organisation (2020). Basic protective measures against the new coronavirus. Retrieved from https://www.who.int/emergencies/diseases/novel-coronavirus-2019/advice-for-public

10. Park M, Cook AR, Lim J, Sun Y, Dickens B. A Systematic Review of COVID-19 Epidemiology Based on Current Evidence. J Clin Med. 2020;9(4):967.

11. Harapan H, Itoh N, Yufika A, Winardi W, Keam S, Te H, et al. The COVID-19 pandemic calls for spatial distancing and social closeness: not for social distancing! J Infect Public Health. 2020;13(5):667-73.

12. Lin C, Ye R, Xia YL. A meta-analysis to evaluate the effectiveness of real-time PCR for diagnosing novel coronavirus infections. Genet Mol Res. 2015;14(4):15634-41.

13. Viner RM, Russell S, Croker H, Packer J, Ward J, Stansfield C, et al. School closure and management practices during coronavirus outbreaks including COVID-19: a rapid systematic review. Lancet Child Adolesc Heal. 2020;4(5):397-404.

14. Brooks SK, Webster RK, Smith LE, Woodland L, Wessely S, Greenberg N, et al. The psychological impact of quarantine and how to reduce it: rapid review of the evidence. Lancet. 2020;395(10227):912-20.

15. Webster RK, Brooks SK, Smith LE, Woodland L, Wessely S, James R. How to improve adherence with quarantine: Rapid review of the evidence. medRxiv. 2020; doi.org/10.1101/2020.03.17.20037408

16. Mahtani KR, Heneghan C, Aronson JK. What is the evidence for social distancing during global pandemics? A rapid summary of current knowledge. Oxford: Oxford Unversity. Retrieved from https://www.phc.ox.ac.uk/files/covid-19-evidence-service/what-is-the-evidence-for-social-distancing-duringglobal-pandemics-final-1.pdf/view

17. Rashid H, Ridda I, King $\mathrm{C}$ et al. Evidence compendium and advice on social distancing and other related measures for response to an influenza pandemic. Paediatr Respir Rev. 2015;16(2):119-26.

18. Fong M, Gao Hi, Wong J, Xiao J, Shiu E, Ryu S, et al. Nonpharmaceutical Measures for Pandemic Influenza in Nonhealthcare Settings-Social Distancing Measures. Emerg Infect Dis. 2020;26(5):976-84.

19. Ferguson N, Laydon D, Nedjati-Gilani G, Imai N, Ainslie K, Baguelin M, et al. Report 9 - Impact of non-pharmaceutical interventions (NPIs) to reduce COVID-19 mortality and healthcare demand. London: Imperial College London. Retrieved from https://www.imperial.ac.uk/mrc-global-infectious-diseaseanalysis/covid-19/report-9-impact-of-npis-on-covid-19/

20. Lai S, Ruktanonchai NW, Zhou L, et al. Effect of non-pharmaceutical interventions to contain COVID-19 in China. Nature. 2020;10.1038/s41586-0202293-x. doi:10.1038/s41586-020-2293-x

21. Bayham J, Fenichel E. Impact of school closures for COVID-19 on the US health-care workforce and net mortality: a modelling study. Lancet Public Heal. 2020;5:e271-8.

22. Hellewell J, Abbott S, Gimma A, Bosse NI, Jarvis C, Russell T, et al. Feasibility of controlling COVID-19 outbreaks by isolation of cases and contacts. Lancet Glob Heal. 2020;8(4):e488-96.

23. Prem K, Liu Y, Russell T, Kucharski A, Eggo R, Davies N, et al. The effect of control strategies to reduce social mixing on outcomes of the COVID-19 epidemic in Wuhan, China: a modelling study. Lancet Public Heal. 2020;5:e261-70.

24. Koo JR, Cook AR, Park M, Sun Y, Sun H, Lim JT, et al. Interventions to mitigate early spread of SARS-CoV-2 in Singapore: a modelling study. Lancet Infect Dis. 2020;

25. Tang B, Xia F, Tang S, Bragazzi N, Li Q, Sun X, et al. The effectiveness of quarantine and isolation determine the trend of the COVID-19 epidemics in the final phase of the current outbreak in China. Int J Infect Dis. 2020;95:288-93.

26. Tang B, Wang X, Li Q, Bragazzi N, Tang S, Xiao Y, et al. Estimation of the Transmission Risk of the 2019-nCoV and Its Implication for Public Health Interventions. J Clin Med. 2020;9(2):462.

27. Rocklöv J, Sjödin H, Wilder-Smith A. COVID-19 outbreak on the Diamond Princess cruise ship: estimating the epidemic potential and effectiveness of public health countermeasure. J Travel Med. 2020;27(3).

28. Panovska-Griffiths J. Can mathematical modelling solve the current Covid-19 crisis? BMC Public Health. 2020;20(1):551.

29. Chu DK, AkI EA, Duda S, et al. Physical distancing, face masks, and eye protection to prevent person-to-person transmission of SARS-CoV-2 and COVID19: a systematic review and meta-analysis. Lancet. 2020;S0140-6736(20)31142-9. doi:10.1016/S0140-6736(20)31142-9

30. Nussbaumer-Streit B, Mayr V, Dobrescu A, Chapman A, Persad E, Klerings I, et al. Quarantine alone or in combination with other public health measures to control COVID-19: a rapid review. Cochrane database Syst Rev. 2020;4:CD013574. 
31. Jefferson T, Del Mar CB, Dooley L, et al. Physical interventions to interrupt or reduce the spread of respiratory viruses. Cochrane Database Syst Rev. 2011;2011(7):CD006207. doi:10.1002/14651858.CD006207.pub4

32. University of Michigan (2020). Michigan Medicine projections show aggressive social distancing will dramatically reduce the peak number of hospitalized COVID-19 patients. Retrieved from https://www.uofmhealth.org/news/archive/202003/michigan-medicine-projections-show-aggressive-social

33. Gough D, Oliver S, Thomas J. An Introduction to Systematic Reviews. 2nd ed. London: Sage; 2017.

34. Moher D, Liberati A, Tetzlaff J, Altman D. Preferred Reporting Items for Systematic Reviews and Meta-Analyses: The PRISMA Statement. PLoS Med. 2009;6(7):e1000097.

35. Moola S, Munn Z, Tufanaru C, Aromataris E, Sears K, Sfetcu R, et al. Chapter 7: Systematic reviews of etiology and risk. In: Aromataris E, Munn Z (Editors). In Joanna Briggs Institute Reviewer's Manual. The Joanna Briggs Institute; 2017.

36. Lockwood C, Munn Z, Porritt K. Qualitative research synthesis: methodological guidance for systematic reviewers utilizing meta-aggregation. Int J Evidence-Based Healthc. 2015;13(3):179-87.

37. Borenstein M, Hedges L, Higgins J et al. Introduction to meta- analysis. Chichester: Wiley; 2009.

38. Thomas J, Harden A. Methods for the thematic synthesis of qualitative research in systematic reviews. BMC Med Res Methodol. 2008;8.

39. Atchison C, Bowman L, Vrinten C, Redd R, Pristerà P, Eaton J, et al. Perceptions and behavioural responses of the general public during the COVID-19 pandemic: A cross-sectional survey of UK Adults. medRxiv. 2020; doi.org/10.1101/2020.04.01.20050039

40. Cowling BJ, Ali S, Ng T, Tsang T, Li J, Fong M, et al. Impact assessment of non-pharmaceutical interventions against coronavirus disease 2019 and influenza in Hong Kong: an observational study. Lancet Public Heal. 2020;5:e279-88.

41. Rugarabamu S, Ibrahim M, Byanaku A. Knowledge, attitudes, and practices (KAP) towards COVID-19: A quick online cross-sectional survey among Tanzanian residents. medRxiv.2020; doi.org/10.1101/2020.04.26.20080820.

42. Williams SN, Armitage CJ, Dienes K. Public perceptions and experiences of social distancing and social isolation during the COVID-19 pandemic: A UKbased focus group study. medRxiv. 2020; doi.org/10.1101/2020.04.10.20061267

43. Wolf MS, Serper M, Opsasnick L, et al. Awareness, Attitudes, and Actions Related to COVID-19 Among Adults With Chronic Conditions at the Onset of the U.S. Outbreak: A Cross-sectional Survey. Ann Intern Med. 2020;M20-1239. doi:10.7326/M20-1239

44. Zhong BL, Luo W, Li H, Zhang Q, Liu X, Li WT, et al. Knowledge, attitudes, and practices towards COVID-19 among Chinese residents during the rapid rise period of the COVID-19 outbreak: a quick online cross-sectional survey. Int J Biol Sci. 2020;16(10):1745-52.

45. Gallè F, Sabella E, Da Molin G, De Giglio O, Caggiano G, Di Onofrio V, et al. Understanding Knowledge and Behaviors Related to CoViD-19 Epidemic in Italian Undergraduate Students: The EPICO Study. Int J Environ Res Public Health. 2020;17(10):3481.

46. Geldsetzer P. Knowledge and Perceptions of COVID-19 Among the General Public in the United States and the United Kingdom: A Cross-sectional Online Survey. Ann Intern Med. 2020;1-4.

47. Hawryluck L, Gold WL, Robinson S, Pogorski S, Sandro G, Rima S. SARS Control and Psychological Effects of Quarantine, Toronto, Canada. Emerg Infect Dis. 2004;10(7):1206-12.

48. Katz R, Vaught A, Simmens S. Local Decision Making for Implementing Social Distancing in Response to Outbreaks. Public Health Rep. 2019;134(2):1504.

49. Meier K, Glatz T, Guijt MC, Piccininni M, van der Meulen M, Atmar K, et al. Public perspectives on social distancing and other protective measures in Europe: a cross-sectional 1 survey study during the COVID-19 pandemic. medRxiv. 2020; doi.org/10.1101/2020.04.02.20049676

50. Pan A, Liu L, Wang C, et al. Association of Public Health Interventions With the Epidemiology of the COVID-19 Outbreak in Wuhan, China. JAMA. 2020;323(19):1-9. doi:10.1001/jama.2020.6130

51. Rios-González C. Knowledge, attitudes and practices towards COVID-19 in Paraguayans during outbreaks: a quick online survey. 2020.

52. Roy D, Tripathy S, Kar SK, Sharma N, Verma SK, Kaushal V. Study of knowledge, attitude, anxiety \& perceived mental healthcare need in Indian population during COVID-19 pandemic. Asian J Psychiatr. 2020;51:102083. doi:10.1016/j.ajp.2020.102083

53. Al-Hanawi MK, Angawi K, Alshareef N, Qattan AMN, Helmy HZ, Abudawood Y, et al. Knowledge, Attitude and Practice Toward COVID-19 Among the Public in the Kingdom of Saudi Arabia: A Cross-Sectional Study. Front Public Heal. 2020;8.

54. Liu M, Cheng SZ, Xu KW, et al. Use of personal protective equipment against coronavirus disease 2019 by healthcare professionals in Wuhan, China: cross sectional study. BMJ. 2020;369:m2195.

55. Milne GJ, Xie S. The Effectiveness of Social Distancing in Mitigating COVID-19 Spread: a modelling analysis. medRxiv. 2020; doi.org/10.1101/2020.03.20.20040055

56. The Lancet Child \& Adolescent Health. Pandemic school closures: risks and opportunities. Lancet Child Adolesc Heal. 2020;4(5):341.

57. Azman AS, Luquero FJ. From China: hope and lessons for COVID-19 control [published online ahead of print, 2020 Apr 3]. Lancet Infect Dis. 2020;S1473-3099(20)30264-4. doi:10.1016/S1473-3099(20)30264-4

58. Sjödin H, Wilder-Smith A, Osman S, Farooq Z, Rocklöv J. Only strict quarantine measures can curb the coronavirus disease (COVID-19) outbreak in Italy, 2020. Eurosurveillance. 2020;25(13).

59. European Centre for Disease Prevention and Control (2020). Considerations relating to social distancing measures in response to COVID-19-second update. Retrieved from https://www.ecdc.europa.eu/en/publications-data/considerations-relating-social-distancing-measures-response-covid-19-second

60. Nicol GE, Piccirillo JF, Mulsant BH, Lenze EJ. Action at a Distance: Geriatric Research during a Pandemic. J Am Geriatr Soc. 2020;68(5):922-5 
61. Hiremath P, Suhas KCS, Manjunath M, Shettar M. COVID 19: Impact of lock-down on mental health and tips to overcome. Asian J Psychiatr. 2020;51:102088.

62. Weinfurt KP, Moghaddam FM. Culture and Social Distance: A Case Study of Methodological Cautions. J Soc Psychol. 2001;141(1):101-10. 1.

63. Alobuia WM, Dalva-Baird NP, Forrester JD, Bendavid E, Bhattacharya J, Kebebew E. Racial disparities in knowledge, attitudes and practices related to COVID-19 in the USA. J Public Health (Oxf). 2020;fdaa069. doi:10.1093/pubmed/fdaa069

64. Marmot M, Allen J, Boyce T, Goldblatt P, Morrison J. Health equity in England: The Marmot Review 10 years on. London: Institute of Health Equity; 2020.

65. Pollock AM, Roderick P, Cheng K, Pankhania B. Covid-19: Why is the UK government ignoring WHO's advice? Br Med J. $2020 ; 368$.

66. Regmi K, Gilbert R, Thunhurst C. How can health systems be strengthened to control and prevent an Ebola outbreak? A narrative review. Infect Ecol Epidemiol. 2015;5(1):28877.

67. Wolkewitz M, Puljak L. Methodological challenges of analysing COVID-19 data during the pandemic. BMC Med Res Methodol. 2020;20(1):81.

68. Shokraneh F. Keeping up with studies on covid-19: systematic search strategies and resources. Br Med J. 2020;m1601.

69. Glasziou P. Waste in covid-19 research. Br Med J. 2020;369(m1847).

70. Altmann DM, Douek DC, Boyton RJ. What policy makers need to know about COVID-19 protective immunity. Lancet. 2020;395(10236):1527-9.

71. Takian A, Kiani MM, Khanjankhani K. COVID-19 and the need to prioritize health equity and social determinants of health. Int J Public Health. 2020;10.1007/s00038-020-01398-z. doi:10.1007/s00038-020-01398-z

72. RCPCH (2020). COVID-19 - research evidence summaries. Retrieved from https://www.rcpch.ac.uk/resources/covid-19-research-evidence-summaries

73. European Centre for Disease Prevention and Control. Coronavirus disease 2019 (COVID-19) in the EU/EEA and the UK-eighth update. 2020. Retrieved from https://www.ecdc.europa.eu/sites/default/files/documents/covid-19-rapid-risk-assessment-coronavirus-disease-2019-eighth-update-8-april2020.pdf

74. Kupferschmidt K. Why do some COVID-19 patients infect many others, whereas most don't spread the virus at all? Science (80-). 2020. Retrieved from https://www.sciencemag.org/news/2020/05/why-do-some-covid-19-patients-infect-many-others-whereas-most-don-t-spread-virus-all

75. Mantovani A, Dalbeni A, Beatrice G. Coronavirus disease 2019 (COVID-19): we don't leave women alone. Int J Public Health. 2020;65(3):235-6.

76. Abel T, McQueen D. The COVID-19 pandemic calls for spatial distancing and social closeness: not for social distancing! Int J Public Health. 2020 Apr 1;65(3):231.

\section{Figures}


Fig. 1

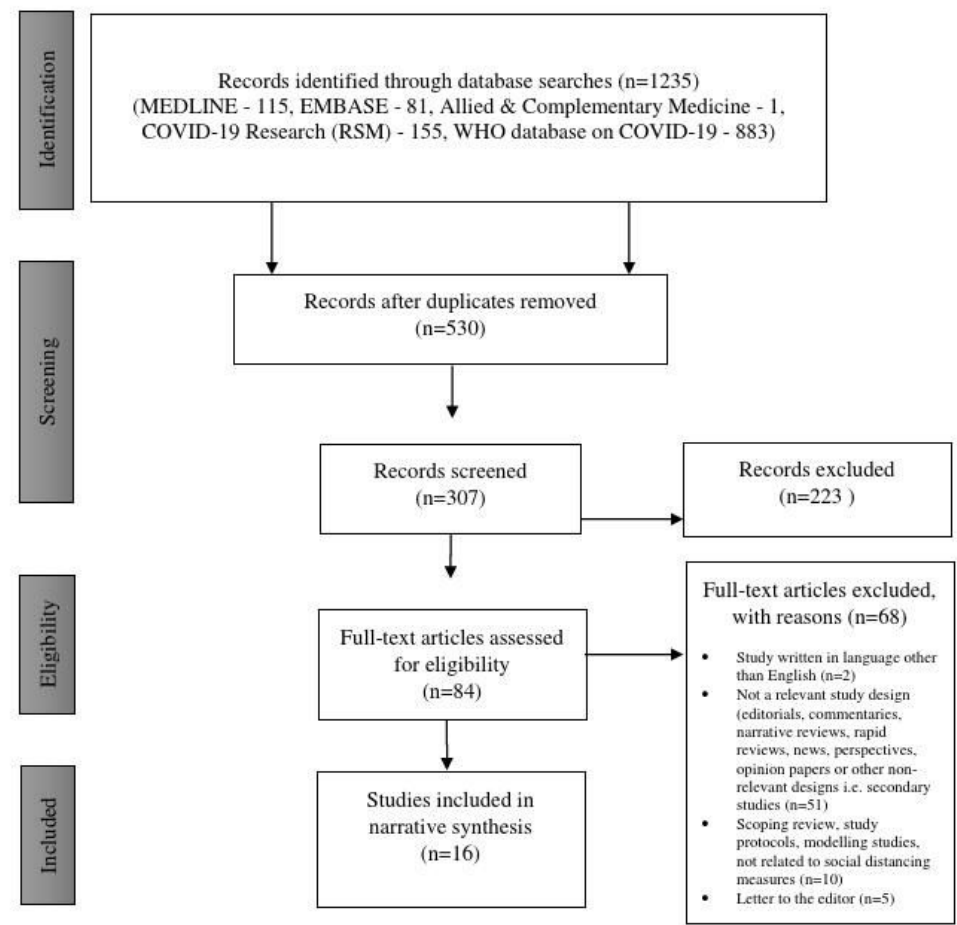

\section{Figure 1}

PRISMA Flow diagram to show results of searches. 


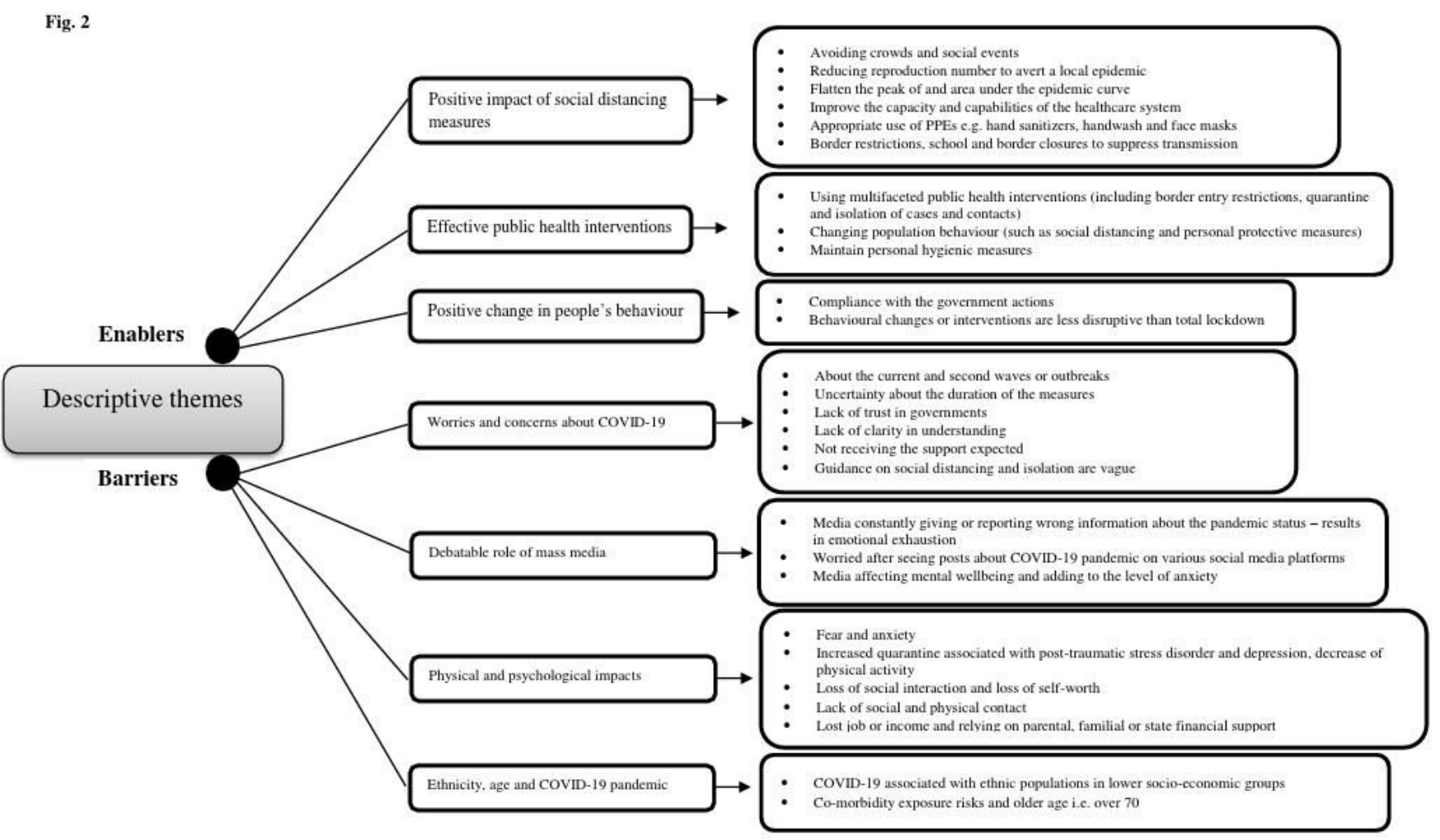

Figure 2

Themes identified across studies of social distancing measures and COVID-19. 
Fig. 3

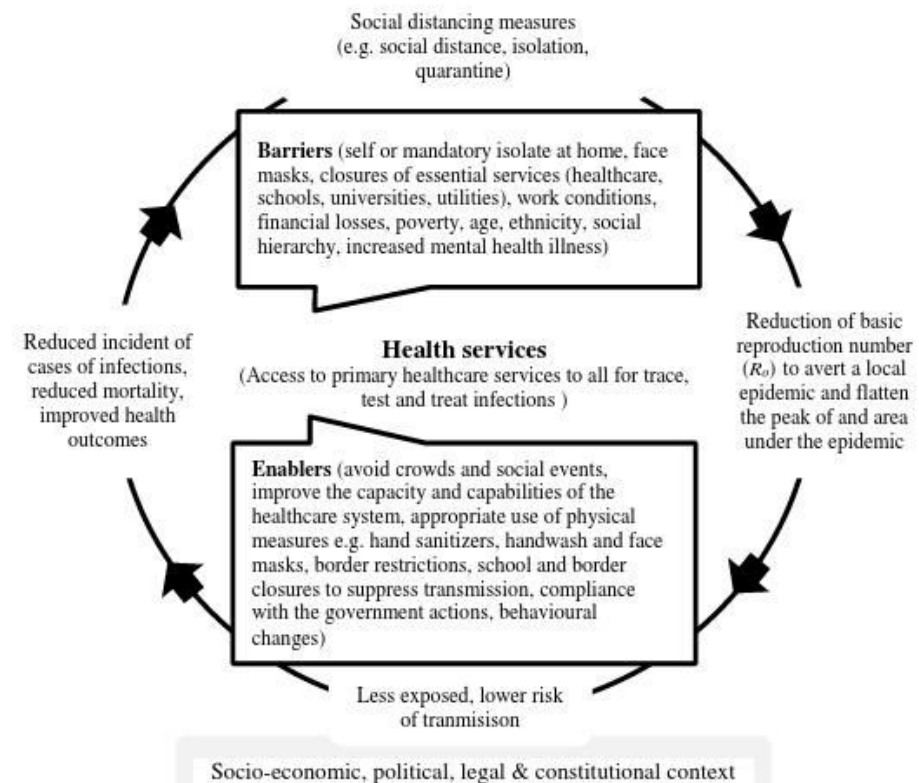

Figure 3

A conceptual framework - the interconnection of social distancing measures, factors and reducing COVID-19.

\section{Supplementary Files}

This is a list of supplementary files associated with this preprint. Click to download.

- Additionalfile3Criticalappraisal180620.docx

- Additionalfile2PRISMA2009checklist1806.docx

- Additionalfile1Systematicrevproto1806.docx 